\title{
ANALISIS CASH HOLDING BERBASIS KEKUATAN KAS DAN MODAL KERJA BERSIH
}

\author{
AnggitaWindi Astuti ${ }^{1}$, Gendro Wiyono ${ }^{2}$, Mujino $^{3}$ \\ ${ }^{1}$ Fakultas Ekonomi Universitas Sarjanawiyata Tamansiswa \\ Yogyakarta \\ Email: anggitawindi.a@gmail.com \\ ${ }^{2}$ Fakultas Ekonomi Universitas Sarjanawiyata Tamansiswa \\ Yogyakarta \\ Email: gw1@doctor.com \\ ${ }^{3}$ Fakultas Ekonomi Universitas Sarjanawiyata Tamansiswa \\ Yogyakarta \\ Email: mujino@ustjogja.ac.id
}

\begin{abstract}
Penelitian ini bertujuan untuk mengetahui pengaruh arus kas, siklus konversi kas, dan modal kerja bersih terhadap cash holding baik secara parsial maupun simultan. Populasi yang digunakan dalam penelitian ini adalah 21 perusahaan subsektor makanan dan minuman yang terdaftar di Bursa Efek Indonesia pada periode 2014-2018. Sampel yang digunakan menggunakan metode purposive sampling. Teknik analisis data yang digunakan adalah metode analisis regresi berganda dengan tingkat signifikan dan pengujian hipotesis menggunakan uji F dan uji t. Dari hasil penelitian, dapat disimpulkan bahwa arus kas tidak berpengaruh terhadap cash holding. Variabel siklus konversi tunai memiliki efek negatif yang signifikan pada memegang uang tunai. Variabel modal kerja bersih memiliki pengaruh positif signifikan terhadap kepemilikan kas. Sementara variabel simultan dari arus kas, siklus konversi tunai, dan modal kerja bersih mempengaruhi kas memegang perusahaan subsektor makanan dan minuman yang terdaftar di Bursa Efek Indonesia pada periode 2014-2018.
\end{abstract}

Kata kunci: Kekuatan Kas, Siklus Konversi Tunai, Modal Kerja Bersih Dan Cash Holding

This study aims to determine the effect of cash flow, cash conversion cycle, and net working capital on cash holding both partially and simultaneously. The population used in this study were 21 food and beverages sub-sector companies listed on the Indonesia Stock Exchange in the 2014-2018 period. The sample used uses the purposive sampling method. The data analysis technique used is the method of multiple regression analysis with a significant level and hypothesis testing using the $F$ test and t test. From the results of the study, it can be concluded that cash flow has no effect on cash holding. Cash conversion cycle variable has a significant negative effect on cash holding. The variable net working capital has a significant positive effect on cash holding. While simultaneous variables of cash flow, cash conversion cycle, and net working capital affect the cash holding of food and beverages sub-sector companies listed on the Indonesia Stock Exchange in the 2014-2018 period.

Keywords: Cash flow, cash conversion cycle, net working capital and cash holding

(C) 2017 JBTI. All rights reserved

Article history : Received 2019-11-18; Revised 2019-11-23; Accepted 2019-11-29 


\section{PENDAHULUAN}

Perusahaan food and beverages merupakan salah satu perusahaan yang terus tumbuh melihat makanan dan minuman yang berperan penting dalam memenuhi kebutuhan pokok manusia menjadi alasan utama pertumbuhan perusahaan food and beverages. Perkembangan perusahaan food and beverages juga ditunjang dengan adanya peningkatan pemanfaatan teknologi terkini sebagai akibat implementasi industri 4.0. Industri food and beverages memiliki prospek kedepan cukup bagus melihat pangsa pasarnya yang besar dan produknya dibutuhkan masyarakat. Menurut Rahmawati (2013) menyatakan bahwa dengan adanya prospek yang bagus, para investor pun tertarik menanamkan modalnya pada perusahaan food and beverages. Kementerian Perindustrian (Kemenperin) dalam (www.antaranews.com) mencatat sepanjang tahun 2018 industri makanan dan minuman dapat tumbuh hingga 7,91\% bahkan melampaui pertumbuhan ekonomi nasional pada angka 5,17\%. Industri makanan dan minuman juga menjadai salah satu sektor yang mendorong peningkatan nilai investasi nasional dimana tahun 2018 menyumbang hingga Rp 56,60 triliun.

Peningkatan nilai investasi nasional membuat banyak investor tertarik untuk menanamkan sahamnya di sektor ini. Salah satu hal penunjang pertumbuhan investasi nasional perusahaan food and beverages tentunya tidak lepas dari analisis fundamental sebagai dasar penilaian perusahaan. Investor tentunya memperhatikan likuiditas perusahaan sebagai dasar utama dalam pertimbangan pengambilan keputusan. Menurut Rahmawati (2013), likuiditas berkaitan dengan kemampuan sebuah perusahaan untuk melunasi kewajiban atau hutang jangka pendeknya. Dikatakan juga bahwa terdapat beberapa aktiva yang temasuk dalam aktiva likuid karena bisa digunakan dengan mudah atau secara langsung untuk melunasi hutang jangka pendek perusahaan, yaitu kas dan setara kas (surat-surat berharga) (Rahmawati, 2013).

Ketersediaan kas dalam suatu perusahaan harus diperhatikan karena dengan adanya kas dapat membantu perusahaan dalam menunjang kelangsungan bisnis yang dijalankan. Perusahaan harus dapat mengelola ketersediaan kas dengan baik agar sesuai dengan kebutuhan perusahaan, karena apabila kas yang digunakan tidak optimal mengakibatkan aktivitas perusahaan tidak dapat dijalankan dengan baik. Oleh sebab itu, menjadi perhatian bagi kalangan eksekutif, analis, maupun investor terhadap penahanan kas (cash holding) untuk mengatur (manage) jumlah kas yang ideal bagi perusahaan (William \& Fauzi, 2013). Dalam menentukan cash holding dapat dipengaruhi oleh kekuatan kas dan modal kerja bersih. Kekuatan kas dapat dilihat dari cash flow dan cash conversion cycle.

Salah satu faktor yang mempengaruhi cash holding yang pertama adalah cash flow atau arus kas. Diperkirakan adanya hubungan yang positif antara cash flow dan cash holding. Pecking order theory menjelaskan bahwa perusahaan akan memegang kas dalam jumlah besar ketika cash flow yang dimiliki tinggi (Bates et al, 2009) dalam (Prasentianto, 2014). Temuan tersebut bertolak belakang dengan penelitian yang dilakukan oleh Rahmawati (2013) yang menemukan bahwa cash flow tidak memberikan pengaruh terhadap cash holding.

Faktor kedua yang mempengaruhi cash holding adalah cash conversion cycle atau siklus konversi kas. Berdasarakan teori packing order theory semakin lama siklus konversi kas, maka semakin besar kebutuhan pendanaan internal peruasahaan untuk membayar kebutuhan bahan baku dan sebaliknya (Wulandari and Setiawan, 2019). Penelitian yang dilakukan oleh Wenny (2017) dan Senjaya \& Yadnyana (2016), justru menemukan bahwa cash conversion cycle tidak berpengaruh terhadap cash holding.

Faktor ketiga yang mempengaruhi cash holding adalah net working capital atau modal kerja bersih. Menurut Anjum \& Malik (2013 dalam Suherman (2017) menjelaskan bahwa peningkatan modal kerja bersih mengarah pada saldo kas yang lebih tinggi karena perusahaan yang likuid cenderung memiliki saldo kas yang lebih tinggi begitupun sebaliknya. Penemuan yang menjelaskan adanya pengaruh net working capital terhadap cash holding bertolak belakang dengan penelitian yang dilakukan oleh penelitian yang dilakukan oleh Bigelli \& Sánchez-Vidal (2012) dan Islam 
(2012) dalam Rahmawati (2013) menemukan tidak adanya pengaruh net working capital terhadap cash holding.

Penelitian tentang cash holding merupakan suatu hal yang menarik untuk diteliti, karena penelitian yang dilakukan menemukan hasil yang bervariasi dan tidak konsisten sehingga menarik untuk dianalisis dan dikaji kembali. Penelitian tentang cash holding juga masih perlu dilakukan karena melihat pentingnya menentukan tingkat cash holding secara tepat bagi perusahaan agar terhindar dari risiko likuidasi dan mengurangi risiko kemungkinan terjadinya financial distress.

\section{KAJIAN TEORI \\ Cash Holding}

Cash holding merupakan salah satu cara perusahaan untuk mengelola kas (Cahyati, Suhendro and Masitoh, 2017). Menurut Ogundipe (2012) dalam Wulandari \& Setiawan (2019), cash holding adalah sejumlah kas dan setara kas yang dimiliki perusahaan yang dengan mudah dapat dikonversikan menjadi uang tunai.

Apabila kas yang dimiliki perusahaan telah tercukupi dan tidak kelebihan maka dapat mengindikasikan perusahaan tersebut likuid. Cash holding memberikan solusi perusahaan dalam hal likuiditas sehingga perusahaan mampu membayar kewajiban tepat waktu di saat kondisi tidak baik. Menurut Prasentianto (2014), pecking order theory adalah apabila biaya pembiayaan meningkat dapat memicu adanya informasi asimetrik, dimana manajemen memiliki informasi lebih luas tentang prospek investasi, risiko, dan nilai perusahaan daripada pemodal publik dengan begitu manajemen bisa menentukan sumber pembiayaan yang lebih murah. Pecking order theory menganggap bahwa tidak ada tingkat cash holding yang optimal tetapi kas memiliki peran sebagai penopang antara kebutuhan investasi dengan laba ditahan.

\section{Cash Flow}

Cash flow merupakan jumlah kas masuk dan keluar perusahaan disebabkan adanya kegiatan operasional perusahaan (Wenny, 2017). Kaitannya dengan cash holding, yang digunakan dalam kegiatan operasional perusahaan adalah kas, besar kecilnya kas dalam perusahaan tergantung pada seberapa besar aliran kas (cash flow) yang ada di perusahaan (Rahmawati, 2013). Menurut Wenny (2017) apabila cash flow masuk lebih besar dari cash flow keluar, menunjukkan cash flow bersih positif dan sebaliknya, apabila cash flow masuk lebih kecil dari cash flow keluar, menyebabkan adanya cash flow bersih negatif. Cash flow bersih positif atau berlimpah artinya perusahaan tidak bergantung dengan pihak eksternal sehingga menyebabkan meningkatnya jumlah kas yang dipegang perusahaan, dan sebaliknya, cash flow bersih negatif menyebabkan turunnya jumlah kas perusahaan.

\section{Cash Conversion Cycle}

Menurut Prasentianto (2014), cash conversion cycle merupakan seberapa lama waktu perusahaan dalam menghasilkan waktunya, dimulai dari membayar biaya untuk mendapatkan persediaan hingga menerima kas dari konsumen atas pembayaran produk jadi. Keterkaitan antara harus diperhatikannya likuiditas perusahaan dan membayar kewajiban kepada kreditur merupakan suatu halyang dapat mempengaruhi siklus konversi kas (Wiyono, 2017). Marfuah \& Zulhilmi (2015) mengatakan bahwa secara teori, perusahaan yang baik maka akan memilki siklus konversi kas yang pendek, dan sebaliknya, memerlukan modal yang banyak disaat siklus konversi kas lebih panjang.

\section{Net Working Capital}

Net working capital merupakan substitusi dari cash holding (Opler et al.) dalam (Bigelli and Sánchez-Vidal, 2012). Modal kerja bersih sebagai kekuatan internal untuk menjalankan kegiatan bisnis yang meliputi kegiatan rutin perusahaan dan membayar kewajiban yang jatuh tempo. Perusahaan yang memiliki modal kerja negatif maka akan membuat cadangan kas. Menurut 
Sapitri (2016), dengan kondisi perusahaan yang meiliki modal kerja negatif atau biasa disebut defisit modal kerja, maka disinyalir perusahaan sedang mengalami kesulitan likuiditas.

\section{Hipotesis \\ Pengaruh Cash Flow Terhadap Cash Holding}

Pecking order theory mengemukakan bahwa perusahaan akan memegang kas dalam jumlah besar ketika memiliki cash flow tinggi Bates et al. (2009) dalam (Prasentianto, 2014). Perusahaan yang memiliki cash flow tinggi diperkirakan menahan kas dalam jumlah besar sebagai akibat dari kecenderungan perusahaan menggunakan pendanaan internal dibandingkan dengan pendanaan eksternal.

Penelitian terdahulu telah dibuktikan oleh Wenny (2017), Prasentianto (2014), Bigelli \& Sánchez-Vidal (2012) dan Wijaya \& Bangun (2019) yang mengemukakan bahwa adanya pengaruh signifikan positif antara cash flow terhadap cash holding. Hal tersebut melandasi hipotesis yang diajukan dalam penelitian ini yaitu:

H1: Cash Flow berpengaruh signifikan positif terhadap Cash Holding.

\section{Pengaruh Cash Conversion Cycle Terhadap Cash Holding}

Cash conversion cycle merupakan waktu perusahaan dalam menghasilkan produk, atas pembayaran biaya untuk mendapatkan persediaan hingga menerima kas dari konsumen dalam bentuk pembayaran atas produk jadi. Berdasarakan packing order theory semakin lama siklus konversi kas, maka semakin besar kebutuhan pendanaan internal peruasahaan untuk membayar kebutuhan bahan baku dan sebaliknya.

Menurut Sapitri (2016), perusahaan dengan siklus konversi kas lama akan menahan kas lebih banyak. Penelitian terdahulu telah dibuktikan oleh William \& Fauzi (2013), Sapitri (2016), Marfuah \& Zulhilmi (2015) serta Wulandari \& Setiawan (2019) mengemukakan bahwa adanya pengaruh signifikan negatif antara cash conversion cycle terhadap cash holding. Hal tersebut dijadikan landasan dalam hipotesis yang diajukan pada penelitian ini yaitu:

H2: Cash Conversion Cycle berpengaruh signifikan negatif terhadap Cash Holding.

\section{Pengaruh Net Working Capital Terhadap Cash Holding}

Net working capital atau modal kerja bersih merupakan hasil pengurangan antara aktivalancar dengan utang lancar. Menurut Anjum \& Malik (2013) dalam Suherman (2017) menjelaskan bahwa peningkatan modal kerja bersih mengarah pada saldo kas yang lebih tinggi karena perusahaan yang likuid cenderung memegang kas yang lebih tinggi begitupun sebaliknya. Kas adalah bagian dari net working capital menciptakan suatu hubungan dimana pada saat kas meningkat maka net working capital juga akan meningkat.

Penelitian terdahulu telah dibuktikan oleh William dan Syarief Fauzi (2013), Jinkar (2013), Sapitri (2016), Marfuah \& Zulhilmi (2015), Suherman (2017), Wenny (2017) serta Wulandari \& Setiawan (2019) mengemukakan bahwa adanya pengaruh signifikan positif antara net working capital terhadap cash holding. Hal tersebut dijadikan landasan hipotesis yang diajukan dalam penelitian ini yaitu:

H3: Net working capital berpengaruh signifikan positif terhadap cash holding.

Pengaruh Cash Flow, Cash Conversion Cycle dan Net Working Capital Terhadap Cash Holding Hasil penelitian yang dilakukan oleh Prasentianto (2014) mengemukakan adanya pengaruh dari cash flow terhadap cash holding, dimana tingginya cash flow berdampak pada meningkatnya cash holding perusahaan.

Hasil penelitian yang dilakukan oleh Sapitri (2016) mengemukakan bahwa cash conversion cycle berpengaruh terhadap cash holding. Penelitian Bigelli \& Sánchez-Vidal (2012) menemukan 
hasil yang sama adanya pengaruh antara cash conversion cycle terhadap cash holding, dimana perusahaan dengan cash conversion cycle yang lama cenderung menahan kas yang besar.

Hasil penelitian yang dilakukan oleh Suherman (2017) dan Wenny (2017) mengemukakan bahwa net working capital berpengaruh terhadap cash holding, dimana net working capital dapat dijadikan subtistusi dari cash holding perusahaan. Berdasarkan penelitian terdahulu tersebut membuktikan bahwa adanya hubungan antara Cash Flow, Cash Conversion Cycle dan Net Working Capital terhadap Cash Holding. Oleh karena itu hipotesis yang diajukan dalam penelitian ini adalah:

H4: Cash flow, cash conversion cycle dan net working capital berpengaruh secara simultan terhadap cash holding

\section{Kerangka Pikir}

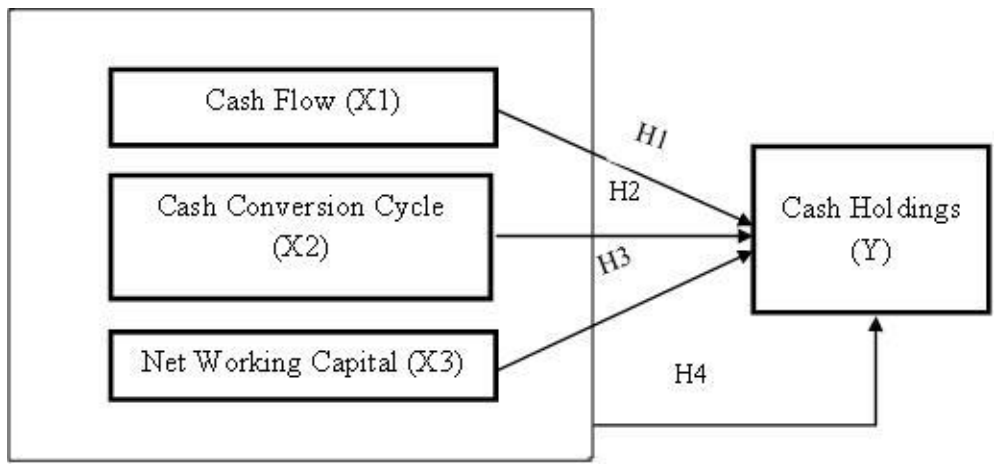

Gambar 1 Kerangka Pikir

Sumber: Puput Sapitri (2016)

\section{METODE PENELITIAN}

Penelitian adalah jenis penelitian kuantitatif yang termasuk dalam penelitian penjelasan (explanatory research) yaitu penelitian yang bertujuan menjelaskan hubungan kausal antara variabel-variabel melalui pengujian hipotesis (Singarimbun dan Efendi) dalam (Rahmawati, 2013). Populasi yang digunakan dalam penelitian ini adalah 21 perusahaan manufaktur sub sektor food and beverages yang terdaftar di Bursa Efek Indonesia pada periode 2014-2015. Sampel yang digunakan dalam penelitian ini menggunakan teknik purposive sampling sehingga total sampel yang telah diseleksi berdasarkan kriteria yang ditetapkan peneliti sehingga diperoleh 55 sampel. Data dikumpulkan dengan metode dokumentasi yang sumbernya dari website Bursa Efek Indonesia (BEI) yaitu www.idx.co.id.

\section{Definisi Operasional}

\section{Cash Holding (Y)}

Variabel dependen yang digunakan adalah cash holding. Rumus untuk menghitung cash holding menggunakan pengukuran yang telah dilakukan oleh Suherman (2017) dan Ogundipe et al ( 2012) adalah :

$$
\text { Cash Holding }(\mathrm{Y})=\frac{\text { Kas dan Setara Kas }}{\text { Total Aset }} \times 100 \%=\ldots \%
$$

\section{Cash Flow (X1)}


Pengukuran untuk menentukan besaran Cash Flow mengacu pada penelitian Ferreira dan Vilela (2004) dan Ozkan (2004) dalam Suherman (2017) menggunakan formula sebagai berikut:

$$
\text { Cash Flow }(\mathrm{X} 1)=\frac{\text { Profit before tax+Depreciation }}{\text { Total Aset }} \times 100 \%=\ldots . \%
$$

\section{Cash Conversion Cycle (X2)}

Pengukuran untuk menentukan besaran Cash Flow mengacu pada penelitian Wenny (2017) dan William \& Fauzi (2013) menggunakan formula sebagai berikut:

$$
\begin{aligned}
C C C(\mathrm{X} 2) & =\text { Days Inventory }+ \text { Days Receivable }- \text { Days Payable } \\
& =\ldots . \text { hari }
\end{aligned}
$$

\section{Dimana:}

Days Inventory

$$
=\frac{\text { Inventory }}{\text { HPP } / 365}=\ldots . . . \text { hari }
$$

Days Receivable

$$
=\frac{365}{\frac{365}{\text { Account Receivable Turnover }}}=\text {......hari }
$$

Days Payabel

$$
=\overline{\text { Account Payable Turnover }}=\text {......hari }
$$

Account Receivable Turnover $=\frac{\text { Penjualan }}{\text { Piutang usaha rata-rata }}=\quad$ kali

Account Receivable Turnover $=\frac{H p p}{\text { Utang usaha rata-rata }}=.$. kali

\section{Net Working Capital (X3)}

Rumus untuk menentukan besarnya net working capital menggunakan rasio net working capital to assets ratio yang mengikuti pengukuran Marfuah \& Zulhilmi (2015), Sapitri (2016) dan William \& Fauzi (2013) adalah:

$$
\text { Net Working Capital }(\mathrm{X} 3)=\frac{\text { Current assets-Current liabilities }}{\text { Total Assets }} \times 100 \%=\ldots \%
$$

\section{HASIL DAN PEMBAHASAN}

\section{Tabel 1 Hasil Analisis Deskriptif}

\begin{tabular}{|l|r|r|r|r|r|}
\hline & $\mathrm{N}$ & Minimum & Maximum & \multicolumn{1}{c|}{ Mean } & $\begin{array}{c}\text { Std. } \\
\text { Deviation }\end{array}$ \\
\hline CFL & 44 & 0,01 & 0,67 & 0,116 & 0,118 \\
CCC & 44 & 0,28 & 16626,47 & 4443,549 & 3797,002 \\
NWC & 44 & 0,00 & 0,20 & 0,063 & 0,063 \\
CHD & 44 & 0,00 & 0,09 & 0,024 & 0,027 \\
Valid N (listwise) & 44 & & & & \\
\hline
\end{tabular}

Sumber: Data olahan SPSS.20, 2019

Pada tabel 1 tersebut dapat diketahui hasil analisis sebagai berikut:

a. Variabel Cash Flow (X1)

Berdasarkan tabel 1 dapat diketahui nilai minimum variabel cash flow (CFL) pada perusahaan manufaktur sub sektor food and beverages dari tahun 2014 sampai dengan tahun 2018 adalah sebesar 0,01; nilai maksimum 0,67; nilai rata-rata sebesar 0,116 , dan nilai standar deviasi sebesar 0,118. Nilai rata rata (mean) lebih kecil dari standar deviasi $0,116<0,118$, berarti sebaran data yang dimiliki cash flow tidak baik.

b. Variabel Cash Conversion Cycle (X2) 
Berdasarkan tabel 1 menunjukkan hasil bahwa variabel cash conversion cycle (CCC) pada perusahaan manufaktur sub sektor food and beverages dari tahun 2014 sampai dengan tahun 2018 memiliki nilai minimum 0,28; nilai maksimum 16626,47; nilai rata-rata sebesar 4443,549; dan nilai standar deviasi sebesar 3797,002. Nilai rata rata (mean) lebih besar dari standar deviasi 4443,549 > 3797,002, berarti sebaran data yang dimiliki cash conversion cycle baik.

c. Variabel Net Working Capital (X3)

Berdasarkan tabel 1 menunjukkan variabel net working capital (NWC) pada perusahaan manufaktur sub sektor food and beverages dari tahun 2014 sampai dengan tahun 2018 memiliki nilai minimum 0,00 ; nilai maksimum 0,20 ; nilai rata-rata sebesar 0,063 ; dan nilai standar deviasi sebesar 0,063 . Nilai rata rata (mean) sama dengan nilai dari standar deviasi $0,063=$ 0,063 , berarti sebaran data yang dimiliki net working capital baik.

d. Variabel Cash Holding (Y)

Berdasarkan tabel 1 menunjukkan variabel cash holding (CHD) pada perusahaan manufaktur sub sektor food and beverages dari tahun 2014 sampai dengan tahun 2018 memiliki nilai minimum 0,00 ; nilai maksimum 0,09 ; nilai rata-rata sebesar 0,024 ; dan nilai standar deviasi sebesar 0,027. Nilai rata rata (mean) lebih kecil dari standar deviasi 0,024<0,027, berarti cash holding memiliki sebaran data yang tidak baik.

\section{Hasil Analisis Regresi Berganda}

Dalam penelitian ini, analisis regresi linear berganda digunakan untuk mengetahui ada tidaknya pengaruh cash flow (CFL), cash conversion cycle (CCC) dan net working capital (NWC) terhadap cash holding (CHD) perusahaan food and beverages. Berikut ini hasil uji analisis regresi berganda yang ditunjukkan pada tabel 2 sebagai berikut:

Tebel 2 Hasil Uji regresi Berganda

\begin{tabular}{|l|l|r|r|r|}
\hline \multicolumn{2}{|c|}{ Model } & \multicolumn{1}{c|}{ B } & t & Sig. \\
\hline \multirow{4}{*}{1} & (Constant $)$ & 0,028 & 3,668 & 0,001 \\
& CFL & $-0,019$ & $-0,570$ & 0,572 \\
& CCC & $-2,224$ & $-2,235$ & 0,031 \\
\multicolumn{2}{|l|}{ a. Dependent Variable: CHD } & 0,130 & 2,060 & 0,046 \\
\hline
\end{tabular}

Sumber: Data olahan SPSS.20, 2019

Berdasarkan tabel 2, dapat dituliskan persamaan regresi berganda sebagai berikut:

$$
\mathrm{CHD}=0,028-0,019 \mathrm{CFL}-2,224 \mathrm{CCC}+0,130 \mathrm{NWC}+e
$$

Persamaan regresi diatas menunjukkan bahwa:

a. Konstanta sebesar -0,028 yang menunjukkan bahwa apabila variabel independen dianggap konstan, maka rata-rata cash holding perusahaan manufaktur sub sektor food and beverages periode 2014 sampai dengan 2018 sebesar $-2,8$ persen.

b. Cash flow (CFL) mempunyai koefisien dengan arah negatif sebesar 0,019. Hal ini menunjukkan bahwa variabel lain dalam keadaan konstan, maka kenaikan CFL sebesar 1 persen akan menurunkan cash holding sebesar -1,9 persen.

c. Cash conversion cycle (CCC) mempunyai koefesien dengan arah negatif sebesar 0,224. Menunjukkan apabila variabel lain dalam keadaan konstan, maka kenaikan CCC sebesar 1 persen akan menurunkan cash holding sebesar -22,4 persen. 
d. Net working capital (NWC) mempunyai koefisien dengan arah positif sebesar 0,130. Menunjukkan apabila variabel lain konstan, maka kenaikan NWC sebesar 1 persen akan menaikkan cash holding sebesar 13 persen.

\section{Hasil Uji Asumsi Klasik}

Uji Normalitas

Hasil uji normalitas dalam penelitian ini dapat disajikan dalam tabel 3 berikut ini:

Tabel 3 Hasil Uji Normalitas One Sample Kolmogorof-Smirnov Test

\begin{tabular}{|l|c|c|}
\hline & \multicolumn{1}{|c|}{$\begin{array}{c}\text { Unstandardized } \\
\text { Residual }\end{array}$} & Keterangan \\
\hline Asymp. Sig. (2-tailed) & 0,394 & Normal \\
\hline a. Test distribution is Normal. & \\
\hline \multicolumn{2}{|l|}{ b. Calculated from data. } & \\
\hline
\end{tabular}

Sumber: Data olahan SPSS.20, 2019

Berdasarkan tabel 3, hasil uji normalitas One Sample Kolmogorof-Smirnov Z dilakukan setelah melakukan beberapa data (trimming) sehingga nilainya menjadi 0,899dan nilai Asymp. Sig. Sebesar 0,394 menunjukkan bahwa nilai Asymp. Sig. Lebih besar dari nilai signifikansi 0,05 sehingga data residual dalam penelitian ini terdistribusi dengan normal.

\section{Uji Multikolinearitas}

Hasil uji multikoliniearitas dapat dilihat pada tabel 4 sebagai berikut:

Tabel 4 Hasil Uji Multikolinearitas

\begin{tabular}{|c|c|c|c|c|}
\hline & \multirow{2}{*}{ Model } & \multicolumn{2}{|c|}{ Collinearity Statistics } & \multirow{2}{*}{ Keterangan } \\
\hline & & Tolerance & $V I F$ & \\
\hline \multirow{4}{*}{1} & (Constant) & & & \\
\hline & CFL & 0,906 & 1,104 & Tidak terjadi Multikolinearitas \\
\hline & $\mathrm{CCC}$ & 0,987 & 1,014 & Tidak terjadi Multikolinearitas \\
\hline & NWC & 0,895 & 1,117 & Tidak terjadi Multikolinearitas \\
\hline
\end{tabular}

Sumber: Data olahan SPSS.20, 2019

Tabel 4 menunjukkan seluruh variabel independen dengan VIF kurang dari 5 dan tolerance lebih dari 0,1 , dapat dikatakan tidak adanya keterkaitan antara satu variabel independen dengan variabel independen lainnya. Disimpulkan bahwa variabel yang digunakan dalam penelitian ini tidak terjadi gejala multikolinearitas.

\section{Uji Autokorelasi}

Hasil uji autokorelasi dalam penelitian ini dapat ditunjukkan pada tabel 5 sebagai berikut:

Tabel 5 Hasil Uji Autokorelasi

\begin{tabular}{|l|r|}
\hline & Unstandardized Residual \\
\hline Asymp. Sig. (2-tailed) & 0,286 \\
\hline a. Median & \\
\hline
\end{tabular}

Sumber: Data olahan SPSS.20, 2019

Berdasarkan tabel 5 ditunjukkan bahwa nilai Asymp. Sig. sebesar 0,286. Nilai tersebut lebih besar dari nilai signifikan yaitu 0,05 sehingga dapat disimpulkan bahwa dalam penelitian ini tidak terjadi 
korelasi yang antara residual pada satu pengamatan dengan pengamatan lain pada model regresi atau tidak terjadi gejala autokorelasi.

\section{Uji Heterokedastisitas}

Hasil uji heterokedastisitas dalam penelitian ini dapat ditunjukkan dengan tabel 6 sebagai berikut:

Tabel 6 Hasil Uji Heterokedastisitas

\begin{tabular}{|l|l|l|c|c|}
\hline \multicolumn{2}{|c|}{} & $\begin{array}{c}\text { Unstandardized } \\
\text { Residual }\end{array}$ & \multicolumn{1}{c|}{ Keterangan } \\
\hline \multirow{3}{*}{$\begin{array}{l}\text { Spearman's } \\
\text { Rho }\end{array}$} & CFL & Sig. (2-tailed) & 0,529 & Tidak Terdapat Heterokedastisitas \\
\cline { 2 - 5 } & CCC & Sig. (2-tailed) & 0,879 & Tidak Terdapat Heterokedastisitas \\
\cline { 2 - 5 } & NWC & Sig. (2-tailed) & 0,925 & Tidak Terdapat Heterokedastisitas \\
\hline
\end{tabular}

Sumber: Data olahan SPSS.20, 2019

Berdasarkan tabel 6 di atas, melalui uji Spearman's Rho dapat diperoleh hasil yang menunjukkan bahwa nilai signifikansi masing-masing variabel independen lebih besar dari 0,05. Dengan demikian dapat disimpulkan bahwa tidak terjadi heterokedastisitas pada penelitian ini.

\section{Uji t}

Berikut hasil uji t yang dapat ditunjukkan oleh tabel 7:

Tabel 7 Hasil Uji t

\begin{tabular}{|l|l|r|r|r|}
\hline \multicolumn{2}{|c|}{ Model } & \multicolumn{1}{c|}{ B } & \multicolumn{1}{c|}{ t } & \multicolumn{1}{c|}{ Sig. } \\
\hline \multirow{4}{*}{1} & (Constant) & 0,028 & 3,668 & 0,001 \\
\cline { 2 - 5 } & CFL & $-0,019$ & $-0,570$ & 0,572 \\
\cline { 2 - 5 } & CCC & $-2,224$ & $-2,235$ & 0,031 \\
\cline { 2 - 5 } & NWC & 0,130 & 2,060 & 0,046 \\
\hline \multicolumn{2}{|l}{ a. Dependent Variable: CHD } \\
\hline
\end{tabular}

Sumber: Data olahan SPSS.20, 2019

Koefisien regresi digunakan untuk mengetahui menguji pengaruh cash flow, cash conversion cycle, net working capital terhadap cash holding. Hasil pengujian tersebut adalah sebagai berikut:

1) Pengujian Hipotesis Pertama

Berdasarkan hasil uji t diperoleh nilai $\beta$ sebesar $-0,019$ sehingga memiliki pengaruh cash flow adalah berlawan arah terhadap cash holding. Memiliki t hitung sebesar -0,570 dengan probabilitas sebesar 0,572. Hasil ini menunjukkan tidak adanya pengaruh antara cash flow terhadap cash holding perusahaan manufaktur sub sektor food and beverages yang terdaftar di Bursa Efek Indonesia periode 2014-2018. Melihat hasil tersebut tidak sesuai dengan hipotesis awal yang diajukan yaitu cash flow berpengaruh signifikan positif terhadap cash holding. Kesimpulannya hipotesis pertama ditolak karena tidak terbukti.

2) Pengujian Hipotesis Kedua

Berdasarkan hasil uji t diperoleh nilai $\beta$ sebesar -2,224 menunjukkan pengaruh cash conversion cycle berlawan arah terhadap cash holding. Memiliki t hitung sebesar -2,235 serta nilai probabilitas sebesar 0,031. Hasil ini menunjukkan adanya pengaruh negatif antara cash conversion cycle terhadap cash holding perusahaan manufaktur sub sektor food and beverages yang terdaftar di Bursa Efek Indonesia periode 2014-2018. Hasil tersebut sejalan dengan hipotesis awal yang diajukan yaitu cash conversion cycle berpengaruh signifikan negatif terhadap cash holding. Kesimpulannya hipotesis kedua diterima karena terbukti.

3) Pengujian Hipotesis Ketiga

Berdasarakan hasil uji t diperoleh nilai $\beta$ sebesar 0,130 sehingga pengaruh net working capital terhadap cash holding adalah searah. Mempunyai t hitung sebesar 2,060 serta nilai probabilitas sebesar 0,046. Hasil ini menunjukkan adanya pengaruh positif antara net working capital 
terhadap cash holding perusahaan manufaktur sub sektor food and beverages yang terdaftar di Bursa Efek Indonesia periode 2014-2018. Hasil ini sejalan dengan hipotesis awal yang diajukan yaitu net working capital berpengaruh signifikan positif terhadap cash holding. Kesimpulannya hipotesis ketiga diterima karena terbukti.

\section{Uji Koefisien Determinasi ( $R$ Square)}

Hasil uji koefisian determinasi pada penelitian ini dapat ditunjukkan dengan tabel 9 sebagai berikut:

Tabel 9 Hasil Uji Koefisien Determinasi

\begin{tabular}{|l|r|r|r|r|}
\hline Model & $R$ & $R$ Square & $\begin{array}{c}\text { Adjusted } R \\
\text { Square }\end{array}$ & $\begin{array}{c}\text { Std. Error of the } \\
\text { Estimate }\end{array}$ \\
\hline 1 & $0,455^{\mathrm{a}}$ & 0,207 & 0,148 & 0,02462 \\
\hline \multicolumn{2}{|l}{ a. Predictors: (Constant), NWC, CCC, CFL } \\
\hline \multicolumn{2}{|l}{ b. Dependent Variable: CHD } \\
\hline
\end{tabular}

Sumber: Data olahan SPSS.20, 2019

Tabel 9 menunjukkan bahwa penelitian ini memiliki nilai R Square sebesar 0,207. Hal tersebut menunjukkan bahwa nilai 0,207 > 1 sehungga dapat disimpulkan bahwa variabel independen yaitu cash flow, cash conversion cycle dan net working capital memberikan informasi cukup besar yang digunakan dalam memprediksi variasi variabel dependen yaitu cash holding. Hasil tersebut juga menunjukkan bahwa cash holding dipengaruhi oleh cash flow, cash conversion cycle dan net working capital sebesar 20,7\% sedangkan sisanya sebesar 79,3\% dipengaruhi faktor lain yang tidak diteliti dalam penelitian ini.

\section{Uji F}

Hasil pengujian statistik F pada penelitian inidapat ditunjukkan pada tabel 8 sebagai berikut:

Tabel 8 Hasil Uji Statistik F

\begin{tabular}{|c|c|c|c|c|c|c|}
\hline \multicolumn{7}{|c|}{ ANOVA $^{\mathrm{a}}$} \\
\hline \multicolumn{2}{|c|}{ Model } & \multirow{2}{*}{$\begin{array}{r}\begin{array}{l}\text { Sum of } \\
\text { Squares }\end{array} \\
0,006\end{array}$} & \multirow{2}{*}{$\begin{array}{r}d f \\
3\end{array}$} & \multirow{2}{*}{$\begin{array}{r}\text { Mean Square } \\
0,002\end{array}$} & \multirow{2}{*}{$\begin{array}{l}\mathrm{F} \\
3,482\end{array}$} & \multirow{2}{*}{$\begin{array}{l}\text { Sig. } \\
0,024^{\mathrm{b}}\end{array}$} \\
\hline & Regression & & & & & \\
\hline 1 & Residual & 0,024 & 40 & 0,001 & & \\
\hline & Total & 0,031 & 43 & & & \\
\hline \multicolumn{7}{|c|}{ a. Dependent Variable: CHD } \\
\hline \multicolumn{7}{|c|}{ b. Predictors: (Constant), NWC, CCC, CFL } \\
\hline
\end{tabular}

Sumber: Data olahan SPSS.20, 2019

Tabel 8 menunjukkan nilai signifikansi sebesar $0,024<0,05$ yang berarti sesuai dengan dasar pengambilan keputusan apabila nilai signifikansi kurang dari 0,05 maka akan diterima. Hal tersebut menunjukkan bahwa cash flow, cash conversion cycle dan net working capital secara simultan berpengaruh terhadap cash holding. Maka hipotesis keempat terbukti. Hipotesis cash flow, cash conversion cycle dan net working capital secara simultan berpengaruh terhadap cash holding diterima karena terbukti.

\section{Pembahasan \\ Pengaruh Cash Flow terhadap Cash Holding}


Cash flow mempunyai koefisien regresi sebesar -0,019 dengan probabilitas sebesar 0,572 serta mempunyai nilai t hitung sebesar -0,570. Hasil ini menunjukkan bahwa cash flow tidak berpengaruh atau tidak signifikan terhadap cash holding perusahaan manufaktur sub sektor food and beverages yang terdaftar di Bursa Efek Indonesia periode 2014-2018 sehingga hipotesis awal ditolak. Hasil yang tidak sejalan dengan hipotesis awal dan pecking order theory, hal ini disebabkan perusahaan yang biasanya memiliki sister company atau anak perusahaan memberikan kemudahan dalam memperoleh pendanaan eksternal (leverage) (Jinkar, 2013). Hal tersebut menyebabkan pendanaan internal tidak terlalu berpengaruh terhadap perusahaan manufaktur sub sektor food and beverages.

Hasil tersebut sejalan dengan penelitan yang dilakukkan oleh Suherman (2017) dan Jinkar (2013) mengemukakan bahwa cash flow tidak berpengaruh terhadap cash holding.

\section{Pengaruh Cash Conversion Cycle terhadap Cash Holding}

Cash conversion cycle mempunyai koefisien regresi sebesar -2,224 dengan probabilitas sebesar 0,031 serta mempunyai nilai t hitung sebesar -2,235. Hasil ini menunjukkan bahwa cash conversion cycle berpengaruh negatif dan signifikan terhadap cash holding perusahaan manufaktur sub sektor food and beverages yang terdaftar di Bursa Efek Indonesia periode 2014-2018 sehingga hipotesis awal diterima. Hasil tersebut dapat disebabkan perputaran kas dari siklus konversi kas akan mempengaruhi saldo kas pada waktu tertentu. Waktu yang lebih pendek dalam proses perputaran kas mengakibatkan semakin cepat cash turnover yang dihasilkannya, dan sebaliknya.

Hasil penelitian sejalan dengan penelitian William \& Fauzi (2013), Sapitri (2016), Marfuah \& Zulhilmi (2015) serta Wulandari \& Setiawan (2019) yang menemukan bahwa cash conversion cycle berpengaruh negatif signifikan terhadap cash holding perusahaan.

\section{Pengaruh Net Working Capital terhadap Cash Holding}

Net working capital mempunyai koefisien regresi sebesar 0,130 dengan probabilitas sebesar 0,046 serta mempunyai nilai t hitung sebesar 2,060. Hasil ini membuktikan bahwa net working capital berpengaruh positif dan signifikan terhadap cash holding perusahaan manufaktur sub sektor food and beverages yang terdaftar di Bursa Efek Indonesia periode 2014-2018 sehingga hipotesis awal diterima. Hal tersebut dapat disebabkan kas merupakan bagian dari net working capital sehingga pada saat kas meningkat, net working capital juga meningkat. Selain itu, aset lancar selain kas tidak dapat menjadi subtitusi bagi kas di setiap saat. Pada beberapa kondisi khusus (sebagai contoh pada saat krisis), aktiva lancar tidak dapat diubah menjadi kas dengan mudah.

Hasil ini sesuai dengan penelitian yang dilakukan oleh William \& Fauzi (2013), Suherman (2017), Sapitri (2016), Wenny (2017), Jinkar (2013) dan Marfuah \& Zulhilmi (2015) yang menyatakan bahwa terdapat hubungan positif net working capital yang signifikan terhadap cash holding.

\section{Pengaruh Cash Flow, Cash Conversion Cycle dan Net Working Capital secara simultan berpengaruh terhadap Cash Holding}

Variabel cash flow, cashconversion cycle cash conversion cycle, dan net working capital mempunyai nilai signifikansi sebesar 0,024 $<0,05$ yang berarti sesuai dengan dasar pengambilan keputusan apabila nilai signifikansi kurang dari 0,05 maka hipotesis awal akan diterima. Hal tersebut menunjukkan bahwa Cash Flow, Cash Conversion Cycle dan Net Working Capital secara simultan berpengaruh terhadap Cash Holding. Maka hipotesis keempat diterima karena terbukti.

Selain itu penelitian ini memiliki nilai $R$ Square sebesar 0,207 $>1$. Hasil tersebut juga menunjukkan bahwa cash holding dipengaruhi oleh cash flow, cash conversion cycle dan net working capital sebesar $20,7 \%$ sedangkan sisanya sebesar 79,3\% dipengaruhi oleh faktor lain yang tidak diteliti dalam penelitian ini.

\section{KESIMPULAN}


Setelah adanya analisis data dan pembahasan yang dilakukan oleh peneliti, maka dapat ditarik kesimpulan dari setiap pengujian hipotesis adalah sebagai berikut:

1. Cash flow berpengaruh negatif tidak signifikan terhadap cash holding dengan nilai koefisien regresi sebesar -0,019 dan signifikan sebesar 0,572 yang berarti tingkat signifikan lebih dari 0,05. Hal tersebut menunjukkan semakin tinggi atau semakin rendah cash flow tidak berdampak pada cash holding.

2. Cash conversion cycle berpengaruh negatif signifikan terhadap cash holding dengan nilai koefisien regresi sebesar -2,224 dengan signifikan sebesar 0,031 yang berarti tingkat signifikan kurang dari 0,05. Hal tersebut menunjukkan bahwa semakin panjang cash conversion cycle akan berdampak pada jumlah kas yang cenderung kecil.

3. Net working capital berpengaruh positif signifikan terhadap cash holding dengan nilai koefisien regresi sebesar 0,130 dengan signifikan sebesar 0,046 yang berarti tingkat signifikan kurang dari 0,05. Hal tersebut menunjukkan bahwa semakin tinggi net working capital akan berdampak semakin tinggi jumlah kas yang dipegang.

4. Cash flow, cash conversion cycle dan net working capital berpengaruh signifikan secara simultan terhadap cash holding dengan nilai signifikan sebesar 0,024 yang berarti tingkat signifikan kurang dari 0,05. Hal tersebut menunjukkan bahwa semakin tinggi cash flow, cash conversion cycle dan net working capital berpengaruh secara bersama-sama terhadap cash holding.

\section{SARAN}

Berdasarkan hasil dan analisa penelitian serta adanya keterbatasan penelitian di atas, maka dapat diberikan saran sebagai berikut:

a. Bagi Perusahaan

Bagi perusahaan diarapkan dapat mengelola jumlah cash holding agar dapat membiayai kegiatan perusahaan dengan baik dan mengindikasikan likuditas perusahaan serta dengan mengelola cash holding perusahaan diharapkan dapat digunakan sebagai investasi untuk masa depan.

b. Bagi Investor

Berdasarakan hasil penelitian ini diketahui bahwa secara parsial cash conversion cycle dan net working capital berpengaruh terhadap cash holding sedangkan cash flow tidak berpengaruh terhadap cash holding. Bagi para investor melihat hal tersebut disarankan untuk memperhatikan faktor cash conversion cycle dan net working capital agar pada masa mendatang investor dapat memperoleh keuntungan serta sebagai alat pengambilan keputusan.

c. Bagi Peneliti Selanjutnya

Bagi peneliti selanjutnya diharapkan dapat memperbaiki keterbatasan yang ada dalam penelitian, memperbanyak jumlah sampel serta tahun pengamatan yang lebih panjang untuk mendapatkan hasil yang menyeluruh. Selain itu peneliti selanjutnya juga diharapkan dapat mengembangkan penelitian dengan memperbanyak faktor lain yang mempengaruhi cash holding selain cash flow karena sudah terbukti dalam penelitian ini bahwa cash flow tidak berpengaruh terhadap cash holding.

\section{DAFTAR PUSTAKA}

Bigelli, M., \& Sánchez-Vidal, J. (2012). Cash Holdings In Private Firms. Journal Of Banking And Finance, 36(1), 26-35. Https://Doi.Org/10.1016/J.Jbankfin.2011.06.004

Cahyati, E. N., Suhendro, \& Masitoh, E. (2017). Pengaruh Net Working Capital, Leverage Dan Agresivitas Pajak Terhadap Cash Holding. (10).

Jinkar, R. T. (2013). Analisa Faktor- Faktor Penentu Kebijakan Cash Holding Perusahaan Manufaktur Di Indonesia. Jurnal Departemen Akuntansi Fakultas Ekonomi Universitas Indonesia Penelitian, 1-19. 
Marfuah, M., \& Zulhilmi, A. (2015). Pengaruh Growth Opportunity, Net Working Capital, Cash Conversion Cycle Dan Leverage Terhadap Cash Holding Perusahaan. Optimum: Jurnal Ekonomi Dan Pembangunan, 5(1), 32. Https://Doi.Org/10.12928/Optimum.V5i1.7819

Prasentianto, H. (2014). Analisis Faktor-Faktor Yang Mempengaruhi Tingkat Cash Holding (Studi Empiris Pada Perusahaan Property Dan Real Estate Yang Terdaftar Di Bursa Efek Indonesia Tahun 2009-2013).

Rahmawati, Z. A. (2013). Faktor-Faktor Yang Mempengaruhi Keputusan Cash Holding Pada Perusahaan Food And Beverages Yang Terdaftar Di Bursa Efek Indonesia (Bei). 1-15.

Sapitri, P. (2016). Pengaruh Net Working Capital, Board Size, Growth Opportunity Dan Cash Conversion Cycle Terhadap Cash Holdings (Studi Empiris Pada Perusahaan Sektor Industri Barang Konsumsi Yang Terdaftar Di Bursa Efek Indonesia Periode 2012-2014).

Senjaya, S. Y., \& Yadnyana, I. K. (2016). Analisis Pengaruh Investment Opportunity Set, Cash Conversion Cycle Dan Corporate Governance Structure Terhadap Cash Holdings. E-Jurnal Ekonomi Dan Bisnis Universitas Udayana, 8, 2549-2578.

Suherman. (2017). Faktor-Faktor Yang Mempengaruhi Cash Holdings Perusahaan Di Bursa Efek Indonesia. Jurnal Manajemen, Xxi(3), 336-349.

Wenny, S. M. (2017). Analisis Faktor-Faktor Yang Mempengaruhi Cash Holdings Pada Perusahaan Manufaktur Yang Terdaftar Di Bursa Efek Indonesia Tahun 2013-2015 (Pengujian Teori Trade-Off).

Wijaya, S. H., \& Bangun, N. (2019). Pengaruh Arus Kas , Leverage , Dan Ukuran Perusahaan Terhadap Cash Holding. Jurnal Multiparadigma Akuntansi, I(2), 495-504.

William, \& Fauzi, S. (2013). Analisis Pengaruh Growth Opportunity, Net Working Capital, Dan Cash Conversion Cycle Terhadap Cash Holdings Perusahaan Sektor Pertambangan. Jurnal Ekonomi Dan Keuangan, 1(2), 72-90.

Wiyono, G. (2017). Efektifitasmanajemen Siklus Konversi Kas Perusahaan Sektor Aneka Usaha Terdaftar Di Bei. Jurnal Ekonomi Dan Keuangan, 1(4), 451-471. Https://Doi.Org/10.24034/J25485024.Y2017.V1.I4.2728

Wulandari, E. A., \& Setiawan, M. A. (2019). Pengaruh Growth Opportunity, Net Working Capital, Cash Conversion Cycle Dan Dividend Payout Terhadap Cash Holding. Jurnal Eksplorasi Akuntansi, 1(3), 1259-1274.

Antaranews.com. "Industri Manufaktur Konsisten Memberikan Kontribusi Paling Besar Terhadap Nilai Ekspor". https://www.antaranews.com/berita/800067/industri-makanan-dan-minumanjadi-sektor-andalan\#mobile-src. 2019 